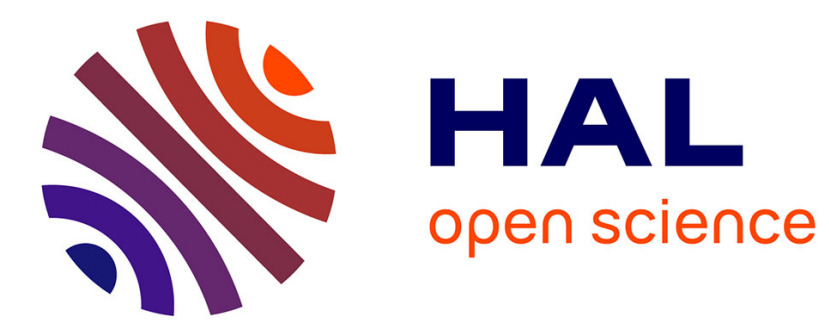

\title{
Islamic economics in real life: Do Muslims give more than the others?
}

\author{
Murat Çokgezen
}

\section{To cite this version:}

Murat Çokgezen. Islamic economics in real life: Do Muslims give more than the others?. 2016. hal-01349872v3

\section{HAL Id: hal-01349872 \\ https://hal.science/hal-01349872v3}

Preprint submitted on 15 Jan 2018

HAL is a multi-disciplinary open access archive for the deposit and dissemination of scientific research documents, whether they are published or not. The documents may come from teaching and research institutions in France or abroad, or from public or private research centers.
L'archive ouverte pluridisciplinaire HAL, est destinée au dépôt et à la diffusion de documents scientifiques de niveau recherche, publiés ou non, émanant des établissements d'enseignement et de recherche français ou étrangers, des laboratoires publics ou privés. 


\title{
Islamic economics in real life: Do Muslims give more than the others?
}

\author{
Murat Çokgezen \\ Marmara University Department of Economics \\ Göztepe Campus 34722 Kuyubaşı \\ Kadıköy-Istanbul/Turkey \\ Tel: +90 216541 4021/ext.1526 \\ Correspondence:mcokgez@marmara.edu.tr
}

Islamic economics in real life: Do Muslims give more than others? 


\section{ABSTRACT}

Islamic economists criticized the value-free nature and unrealistic assumptions of conventional economics and offered a new paradigm based on Islamic behavioral assumptions. The aim of this paper is to explore the validity of these behavioral assumptions, in general, or more specifically, assumptions of Islamic economics (IE) concerning giving.

The validity of behavioral assumptions of IE and their results is rarely questioned in the literature. In particular, empirical studies, in this regard, are very limited. This study aims to make a contribution to this methodological issue by analyzing two comprehensive surveys conducted in the US and Europe.

Results of the study show that more pious people give more than others but it found no difference between giving behavior of Muslims and others. Increasing numbers of studies supporting the findings of this study or raising questions about the validity of Islamic economic assumptions may cause IE to evolve in a different direction.

Keywords: Islamic economics, charity, religion, Zakat, Muslims 
1. Introduction

All major religions believe in the afterlife in one way or another. It is widely believed that after the death of the body, the soul either continues to exist in another world or travels for some time to another world and finally returns again to the earth to continue to live in a different body. The quality of one's afterlife depends on the actions taken in this world. Those who follow the rules of their faith and organize their lives according to their religious principles are rewarded in their afterlife, while those who do the opposite are punished. Therefore, a religion can be defined as a set of rules that should be adopted by the believers for interacting with other people and with God in this world for a better afterlife.

Economics, on the other hand, is a pure "earthly science" that explains how people interact with each other in markets in order to achieve their goals in this world. Like religion, economics tries to set rules about human behavior, but, unlike religion, these rules are about how people actually behave rather than how they should behave. Even some of the explanations of economics are based on behavioral assumptions conflicting with the teachings of almost all religions. For instance, the rules of economics are built on selfish agents who maximize their material well-being. But, the faiths usually promote altruism, and believers are expected to please others and to earn God's pleasure in addition to maximizing their material well-being. Moreover, unlike religious rules, individuals in economics are not tied to any values in their social sphere.

The aforementioned discussion is valid for Islam too. A true Muslim organizes her life according to the words of Allah (Quran) and sayings of the Islamic prophet Muhammad (Hadiths). Teachings in the Quran and of Muhammad, in some aspects, are compatible with economic theory, like the recognition of private property and appreciation of market transactions. However, they are in conflict with some other basic economic principles. For instance, while interest is one of the major prices in markets that allocates resources in economics, it (riba) is strictly banned in Islam. ${ }^{1}$ Again, economics is a value-free science. A

\footnotetext{
${ }^{1}$ Riba ban is mentioned in a number of verses in the Quran. See, for instance, Al-Baqarah (2: 275, 276, 278 and 279), Al-Imran 3:130, Al-Room 30:39.
} 
consumer may choose any good combination with her given income to maximize her utility. Islam, on the other hand, condemns overconsumption and the consumption of certain goods, like alcoholic beverages, pork, gambling, etc., which are banned (Haram).

Due to these controversies, some Muslim economists and theologians have claimed that the conventional paradigm of economics is inadequate to understand Muslim societies, and they have raised the need for Islamic economics (IE), which has grown outside the conventional realm in the last quarter of the twentieth century. ${ }^{2}$ Although a rapidly growing literature has emerged since then, IE is still in its infancy and far from being a comprehensive alternative to its conventional counterpart. The majority of the works are about "how IE is different" from the conventional one; in other words, it is about what IE is not. Studies that explain "what IE is" are still limited, and there is no consensus among them (Mahomedy 2013).

One of the main discussions in IE is about the methodology used. Some Islamic economists consider that a modified version of conventional economics' methodology can be used to study IE (Ahmed 2002); the others are for a unique IE methodology (Zaman 2012). Whichever path is chosen, three characteristics distinguish IE from its conventional counterpart (Kuran 1995): prohibition of interest, redistribution of income through compulsory giving (Zakat) and analysis based on economic agents acting according to Islamic norms. This paper is basically related to the second and third of these characteristics.

Being charitable and providing for the needy are virtuous deeds in Islam. Those who give are promised to be rewarded both on earth and in their afterlife. Helping the fortunate is promoted in almost all faiths, but mandatory giving is available only in Islam and Judaism. Probably for this reason, special importance is given to charity in IE. It is considered a distinguishing feature of the discipline, and compulsory giving (Zakat) is always included in the Muslim economic agent's consumption function (the second characteristic). Giving in these functions does not refer only to Zakat but also to voluntary giving (Sadakah), since Islamic economists always emphasize that, unlike typical selfish economic agents of conventional theory, Muslims behave in an altruistic way, and their utility does not only

\footnotetext{
${ }^{2}$ Although the roots of IE go back to studies of Islamic thinkers like Ibn Khaldun and AI-Ghazali, IE has emerged as a formal discipline in the last quarter of the twentieth century.
} 
depend on their own material consumption but also on helping others (the third characteristic).

This paper explores the validity of these two distinguishing characteristics and their compatibility with real lives of Muslims. A major question posed by this paper, then, is: In general, do these behavioral assumptions of IE overlap with behaviors of Muslims in practice? Or, more specifically, do Muslims give more than others? The research question is of vital importance for the development and future path of IE for several reasons. First, followers of the discipline claim that IE is an alternative to conventional economic theory, which is based on unrealistic assumptions. This implies-at least raises the expectationthat IE is based on realistic assumptions. Therefore, "IS IE based on realistic assumptions?" is the question that Islamic economists who criticize conventional economics should answer. Second, unlike conventional economics, IE is a normative theory that describes an ideal state that can only be achieved if certain behavioral norms are adopted. Do Muslims adopt these norms? If the answer is "No", then "why do they not adopt them?" and "how can they be motivated to adopt these norms?" These are the basic questions to be asked by a normative theory in order to achieve the ideal.

The validity of behavioral assumptions of IE and their results are rarely questioned in the literature. Particularly, empirical studies in this regard are very limited. This study aims to make a contribution to this methodological issue. Additionally, it also provides a contribution to empirical studies on charity giving. The remainder of this paper is organized as follows. The following section discusses the notion of "giving" in Islamic teachings. How charitable giving is adopted in IE is discussed in section three. Section four compares the giving behavior of Muslims with other religions by using two surveys. The final section evaluates the findings and discusses the implications of these findings on IE.

\section{Giving in Islam: Muslims give}

The eradication of poverty and an egalitarian income distribution are the major goals of all religions. A basic tool for achieving these goals is charitable giving, which can take the form of donating money, time, and resources to the needy and has special names, like dana 
in Hinduism and Buddhism and tzedakah in Judaism. Islam is no exception. Muslims are both obliged and encouraged to give to those in need.

In Islamic teaching, it is believed that messengers of Allah were sent to earth to establish justice (Quran 57:25). Justice in the economic sphere basically refers to equality or, more specifically, the equal distribution of income and wealth. This does not mean absolute equality. Inequality originating from skill, effort, or risk differences is admitted, but extreme inequality is ruled out because it is believed that it would destroy the universal brotherhood of human beings, which is one of the most fundamental principles of Islam (tawhid) (Chapra 1992: 211-212; Kuran 1989: 172). This economic justice objective of Islam is expected to be reached through giving.

In Islamic teaching, everything is created by Allah; therefore, all property is ultimately owned by Him. ${ }^{3}$ A legal earthly owner is merely holding the property as a trustee, and her rights to the property are bound by the ultimate owner. Allah, the ultimate owner of everything, obliges and promotes his wealthy trustees to give part of their possessions to their poor brothers. Those who refrain from paying charity are warned about severe punishments from Allah on the day of resurrection in both the Quran and the Hadiths. ${ }^{4}$ Those who fulfill their duties will both multiply their wealth in this world and be rewarded in the hereafter (paradise). ${ }^{5}$ Therefore, charitable giving will help a society to achieve two main economic objectives: "fair" income distribution and growth.

The most important categories of charity defined in Islam are Zakat (obligatory) and Sadaqah (voluntary). As one of the five pillars of Islam, Zakat is a yearly compulsory

\footnotetext{
3 "To Allah does belong the dominion of the heaven and the earth and all that is there in" (Quran 5:20).

${ }^{4}$ For example, in a Hadith, the Prophet Muhammad says, "Whoever is made wealthy by Allah and does not pay the Zakat of his wealth, then on the Day of Resurrection his wealth will be made like a bald-headed poisonous male snake with two black spots over the eyes. The snake will encircle his neck and bite his cheeks and say, 'I am your wealth, I am your treasure'" (Bukhari: Vol. 2 No. 486). See also Quran (64:17, 57:11, and 57:18).

${ }^{5}$ Whoever comes [on the Day of Judgment] with a good deed will have ten times the like thereof [to his credit], and whoever comes with an evil deed will not be recompensed except the like thereof" (Quran 6:160).
} 
donation, which is similar to tax, imposed on wealthy Muslims to meet the redistributive aims of Islamic society. Wealth, above a minimum amount known as Nisab, is subject to Zakat at a varying rate, between 2.5 and 20 percent (Kuran 1989: 179).

Sadaqah is another form of giving in Islam. Although it has the same aim as Zakat and the two words are used interchangeably in some Quranic verses, there are major differences between the two. First, Sadaqah is voluntary and given out of the "heart" rather than wealth. Second, unlike Zakat, which is given once a year, there is no time limit and no material threshold for Sadakah. Third, only goods that have an economic value, like gold, camels, wheat, and so on, are considered as Zakat, but Sadakah may take any form. ${ }^{6}$ Finally, the poor and needy are the main recipients of Sadakah too. However, Sadakah can also be given to neighbors, friends, non-Muslims, and even the rich.

Beyond individual giving, Islam also promotes the institutionalization of giving through endowments (waqf). The creation of a waqf means the dedication of an asset to some charitable ends for the duration of this asset's existence. After the formation of the waqf, the property no longer belongs to an individual and its ownership cannot be transferable to anybody. The establishment of a waqf was first advised and promoted by the Islamic prophet Muhammad, and it has become the major institutional form of Islamic charity over the years. Endowments improve the efficiency of both the collection and the distribution of charitable giving, and have been used extensively in Islamic societies to improve social services (like health, education, water, religious services, etc.) in addition to the well-being of the poor (Hasan 2015).

In the early years of Islam, Zakat was just a moral obligation. It was legislated after the Prophet Muhammad's migration to Madinah in AD 622 and collected and distributed by state officials. However, the state's role in the collection and distribution of Zakat has always been a problematic issue both among Islamic jurists and in Islamic societies. Even in the early years, some tribes refused to pay Zakat to the caliph Abu Bakr, the successor of the Islamic prophet Muhammad. The practice of collecting and distributing Zakat under the supervision

\footnotetext{
${ }^{6}$ Even "Your smile for your brother is charity" (Fiqh-us-Sunnah: Vol. 3 No. 98).
} 
of the state has declined over the years. Today more than half (24) of the predominantly Muslim countries (40) do not legally institutionalize Zakat and leave it to the believers' faith. In the remaining 16 countries, state involvement in the collection and distribution of Zakat takes two forms. In 10 of these 16 countries, the state establishes entities to collect and distribute Zakat, while it is legally enforced in only 6 of them (Powell 2009).

Islamic law places many restrictions on the collection and distribution of Zakat. However, with the changing circumstances in Islamic societies, these restrictions have been reinterpreted and broadened by Islamic scholars over the years. For instance, Zakat was originally levied on assets that grow in value, like gold, silver, animals, crops, and merchandise, and are owned by individuals. However, some modern systems have extended the obligation to corporations, an application that has no precedent in Islamic jurisprudence (Powell 2009). The scope of the Zakat recipients has also been widened gradually. The groups identified in the Quran (9:60) as Zakat recipients-the poor, the needy, those who collect Zakat in the name of the state, new converts to Islam, those in bondage, debtors, anything in the way of God, and wayfarers-are basically individuals. However, the share of Zakat spent on social programs has increased gradually, which may be considered a violation of the traditional figh, since it is possible that donors might benefit from their own contributions. Today, the definition of Zakat-eligible assets and recipients varies across the Muslim countries and the different sects of Islam (Kuran 1995; Powell 2009).

\section{Giving in Islamic economics: Muslims give more}

As mentioned above, giving charity is one of the distinctive features of Islam that will improve the material well-being of both individual Muslims (givers and receivers) and society as a whole. Therefore, Islamic economists adopt giving in their micro- and macroeconomic models as an element that discriminates their work from their conventional counterparts and obtains different results.

The adoption of giving in IE studies begins with a critique of the assumptions of conventional economics; for example, Khan (1987: 24-25) states: "The economist assumes that human beings are selfish, rational, maximizers of their own material well-being and possessors of perfect knowledge in the future ... Islamic economics does not agree with any of these 
assumptions". Their alternative assumption is not as strict as its conventional counterpart: "... man is neither selfish nor altruistic; he is both. He has an inborn tendency to be selfish, to love wealth but he has also been endowed with the ability of being altruistic" (Khan 1987: 25). This assumption is supported by the following: "Secondly, by education altruistic behavior can be cultivated and made persistent. Thirdly, human beings have imperfect foreknowledge ... Fourthly, in ultimate analysis, falah of the Akhira (well-being in the afterlife) is preferable over material progress in this world" (Khan 1987: 25).

Based on the first and fourth assumptions, a typical consumer in Islamic microeconomic analysis allocates her income to two types of spending: to meet her (her family's) material needs, $E_{1}$, and to meet the needs of others (charity), $E_{2}$. The utility function of the consumer consists of these two elements. While material consumption $\left(E_{1}\right)$ shows a diminishing marginal utility property, as in conventional economics, the marginal utility of each additional expenditure for the sake of $\operatorname{God}\left(E_{2}\right)$ is assumed to be constant, $a$. $a$ has a positive relationship with the piety of the consumer (a more God-fearing consumer has a higher $a$ ). Of course, $E_{2}$ is only included in a Nisab consumer's (a wealthy consumer who is obliged to pay Zakat) consumption function and is actually consumed by the receiver of the charity. Therefore, in IE the consumption of the charity receiver is greater than her income, while the reverse is true for the giver. Both components of the consumption are subject to Islamic regulations. A limit of the first component is banned (Haram) goods. The consumption basket of a Muslim is likely to be smaller than that of her counterpart in conventional economics, as it only includes permissible goods, and a true Muslim avoids overconsumption (Israf). A second component of the function is related to giving, and its lower limit is determined by mandatory giving (Zakat). It has no upper limit for spending for others. Those who want to acquire a greater appreciation of Allah will give more voluntarily (Sadaqah) (Khan 1984: 2-11).

Islamic economists apply these individual consumers' behavioral patterns to aggregate models too to obtain some macroeconomic consequences. For instance, after discussing four hypothetical behavioral scenarios, Kahn (1984) concludes that the adoption of Islamic values by consumers (consume moderately, save more, and give to others as much as possible) will improve their well-being, the well-being of the poor, and the well-being of 
society as a whole (higher growth rate). In another study, Ikbal (1985) adopts a very similar methodology to Kahn (1984) and discusses the macroeconomic implications of Islamic injunctions (moderation in consumption and both compulsory and voluntary giving) on consumption. In his macroconsumption function, again, society is divided into two groups. One gives a certain part of its income to the second group as Zakat. He discusses the macroeconomic impacts of imposing giving and moderation in the consumption function and concludes that, while the effect of giving would be expansionary and that of moderation contractionary, the net effect will be ambiguous. This study and Kahn's work (1984) constitute the two pillars of Islamic consumption theory.

To sum up, IE approaches the behavioral assumptions of conventional economics critically and proposes a new economic theory based on Islamic behavioral norms. In fact, conventional economics' behavioral assumptions (self-interested and rational agents) have been criticized by economists with different worldviews and from different subfields of economics and by other social scientists since they were first introduced by nineteenthcentury economists (Rodriguez-Sickert 2009). In recent decades the criticism has reached a peak with empirical and experimental evidence from behavioral economists mounting against these assumptions (Kahneman 2003). All of these critics question the validity of the "self-interested economic agent" of conventional economics and offer a more realistic and more altruistic agent instead, like IE. The major difference between IE and other critical theories is that while IE attributes altruism only to Muslim economic agents, the others consider all economic agents. Hence, a typical consumer who behaves altruistically and spends part of her income for others (charity) in IE is attributed only to Muslims-which implicitly means that Muslims give more than others-and accordingly Muslim societies are considered to perform better in eliminating poverty and unequal income distribution.

The inclusion of giving in Islamic economic models is justified by the references to charitable giving (both Zakat and Sadakah) in Islamic sources. The existence of references to charitable giving in Islamic sources is obvious, but in these sources no comparison is made with nonMuslims. What we can derive from Islamic sources is only that "Muslims give"; attributing altruism and charitable giving only to Muslims-like Islamic economists do-is a much stronger claim than the Islamic sources suggest. 
In the context of this study, one further point about the new economic agent proposed by Islamic economists should be mentioned. Even though there is a broad consensus among Islamic economists on introducing a "Muslim" economic agent (Homoislamicus), who adopts Islamic economic norms in her life, as an integral part of their economic model, whether this new economic agent describes a Muslim in reality or an ideal Muslim is ambiguous.

As they usually begin with a critique of conventional economics which intends to explain how an economy works in reality, and as Islamic economics is presented as an alternative to conventional theory, it is expected that Islamic economics also concerns reality. This is clearly mentioned by Khan (1987: 25): "The Western economists ... have argued that the assumptions need not to be empirically valid. In fact, some have gone to the extent of saying that valid predictions are possible only from invalid assumptions. Islamic economics does not accept this position on the basis of rationality and empiricism".

However, in developing an Islamic theory of economics, Islamic economists lacked a realistic framework (what is) that can provide a basis for understanding the economic behavior of human beings (Khan 2013). Studies usually concentrate on Islamic economic models (what should be) that show an ideal that can be achieved if the Muslim code of behavior is adopted and suggest the inculcation of Islamic values in the life of Muslims through education (Khan F. 1984; Khan M. A. 1987). This is clearly mentioned by Khan (1987: 27) "Islamic economics is a normative discipline. It explores the ways and means to change the existing economies into Islamic economies. Economics (mainstream), on the other hand, claims to be a positive science which studies the existing economic phenomena. Islamic economics is interested in changing the economic reality. Its predictions also relate to a world which has not yet ushered in".

Taking these two points together, one can conclude that, unlike the selfish agent of conventional economics, IE assumes an altruistic economic agent (Homoislamicus) who spends her income not only on herself but also on others through charity. Since this behavioral norm is attributed to Muslims only, this implicitly means that Muslims give more than others. However, whether this behavioral characteristic refers to a Muslim in reality or an ideal Muslim is vague. 


\section{Do Muslims give more than others?}

Studies in the field of charitable giving show that the level of giving changes with respect to religion and religious denomination. However, even in the most comprehensive survey, which reviewed almost 500 studies on giving, that studies comparing giving behavior of different religions are quite few (Bekkers and Wiepking 2007: 7), referring to only three studies-Berger 2006; Everatt, Habib, Maharaj, and Nyar 2005; and Hoge and Yang 1994. In these studies, there is no specific reference to Muslims, probably because Muslims were represented in very small percentages in the samples used in these studies and were, therefore, grouped under the title "other".

There are also studies examining Zakat, or the charitable giving practice of Muslims. These works can be grouped into two categories. The first group of research (Hasan 2015; Malik 2016) proposes that Zakat serves as a unique mechanism that promotes economic growth, improves the well-being of the poor, and contributes to other socially desired outcomes, while the other group (Ahmad 2000; Kuran 1989) illustrates that Zakat is not collected and distributed effectively and, therefore, does not help to alleviate poverty in Muslim societies.

Collection of Zakat has always been a problematic issue for Islamic societies. Although it is not easy to measure, massive withdrawals, which in turn cause liquidity shortages, from the banks in Pakistan where Zakat is compulsory and banks deduct Zakat from the balances held by Pakistani Muslims, indicate the urgency of the evasion problem, at least in this country (DAWN 2002). Again, low Zakat collection rates in Muslim countries-which made Zakat mandatory mostly in the last quarter of the twentieth century prior to the passage of the ordinance (Powell 2009)-can be interpreted as a lack of adopting behavioral norms imposed by Islam and a reluctance to pay Zakat without enforcement of an earthly authority, even more than 1000 thousand years after these rules were imposed.

Distribution of Zakat, in practice, is not exempt from criticism. In the case of individual distribution, the recipients are basically determined by the giver arbitrarily rather than the criteria determined by the Sharia. In giving decisions, those who have proper connections with, and who are in the interest of the giver are favored. Institutionalized distribution mechanisms, which are brought into practice in order to eliminate inefficiencies of the 
individualistic system, are also far from perfect. Anecdotal evidence shows that these institutions-both governmental and non-governmental-also suffer from corruption, nepotism, and political influence, which, in turn, causes a misallocation of Zakat resources (DAWN, 2003; Kuran 1989). For instance, it is alleged that, in Pakistan, Zakat committees openly demand up to 50 percent of the amount claimed, and if the claimant declines the offer, the committee refuses to release the funds (DAWN 2003). In another case, directors of a Turkish Islamic charity were convicted of using the money that had been raised in Germany to help needy Muslims for purposes outside of the charity like buying real estate, setting up private businesses, and financing pro-government media (The Economist 2008).

Although these studies provide counterevidence to IE's assumptions on giving, none of them compare the charitable giving behavior of Muslims with members of other religions. The only study supporting the view of IE is a poll by JustGiving. According to the poll of over 4,000 people in the UK, Muslims give more money to charity than people of other religions. Respondents were asked the question, "How much, if at all, would you say you generally donated to charities last year?" Muslims answered that they donated about $£ 371$ per person per year, with Jews in second place with $£ 270$ per person annually. Christians gave considerably less, and atheists were at the bottom of the list with $f 116$ donated (Gledhill 2013). Nevertheless, the results of the study should be treated with caution since the results are based on a straightforward analysis, and there is no sign of using control variables that allow us to distinguish the impact of being Muslim from other variables that affect giving decisions.

This section is a primary effort to fill this gap. The major aim of this effort is to determine whether Muslims show a significant difference in giving, which justifies the adoption of giving in IE, compared to members of other religions by using two comprehensive surveys from two different parts of the world: the US and Europe.

\subsection{Methodology}

In order to investigate the giving behavior of Muslims and compare their level of giving with the members of other religions, two surveys conducted in two continents are used. One of them is the General Social Survey (GSS) conducted by the National Opinion Research Center 
(NORC) at the University of Chicago and is made freely available to interested parties over the Internet. ${ }^{7}$ NORC polls individuals across the USA on over 800 questions regarding concerns, experiences, attitudes, and practices of US residents. It is one of the most frequently cited social science database in publications. The survey is conducted every other year, but questions about giving were asked only in 2002, 2004, 2012, and 2014. In this study, the 2012 survey is preferred because the number of Muslims surveyed is very limited in all of these GSS surveys, and the 2012 survey was the most recent with the highest number of Muslims.

The second set of data comes from The European Social Survey (ESS), a cross-national survey that has been conducted every two years since 2001. In each survey, face-to-face interviews are conducted with newly selected, cross-sectional samples across Europe. The survey measures the attitudes, beliefs and behavioral patterns of diverse populations in more than thirty nations, consisting of a collection of questions that can be classified into two main parts - a core section and a rotating section. The core section focuses on a range of different themes that are largely the same in each round. The rotating part is dedicated to specific themes, which are sometimes repeated in later rounds. The questions about the giving behavior of the Europeans were asked in the first round of the survey conducted in 2002 under the "Citizen Involvement" section; therefore, the first round of the ESS is used in this study. ${ }^{8}$

In the literature, giving is defined in two ways: Donating and Volunteering. Donating refers to giving of money, whereas volunteerism is the giving of time to a cause. Both types of giving will be examined by using the data obtained from the abovementioned surveys. In these surveys, giving attitudes of the respondents are examined by asking two types of questions. They are either asked if they have donated money or volunteered in the past year (ESS) or the frequency of their giving activities in the past year (GSS), and the possible answers to these questions are in binary and ordered categorical form, respectively.

\footnotetext{
${ }^{7}$ http://gss.norc.org/

${ }^{8}$ The ESS data is also freely available for non-commercial use at http://www.europeansocialsurvey.org
} 
Considering the discrete nature of dependent variable, binary and ordered logit models depending on the form of the giving question- are preferred for estimations. Our model has the following form,

$$
y_{i}^{*}=\beta^{\prime} x_{i}+\varepsilon_{i}
$$

where $y_{i}$ is a latent variable measuring the giving attitude of the respondent $i$ and takes an integer value depending on the type of the survey question. $X_{i}$ is a $(1 \times k)$ vector of observed non-random explanatory variables (Income, Age, Education, Gender, Marital Status, Race, Religiosity, Muslim and Religiosity*Muslim); $\beta$ is a $(k \times 1)$ vector of unknown parameters; and $\varepsilon_{\mathrm{i}}$ is the error term, which is assumed to follow the standard logistic distribution.

Income is one of the major determinants of charitable giving and, as expected, studies indicate that high-income individuals and households contribute more to charities (Bekkers and Wiepking 2007; Lammam and Gabler 2012). The relationship is valid at the macro level as well. Gittel and Tebaldi (2006) found that an increase in a state's per capita income increases the average charitable giving in the US. World Giving Index Reports ${ }^{9}$ also indicate a higher percentage of the population involved in giving activities in richer countries. Therefore, a positive relationship between income and giving, particularly in the form of monetary donation, is also expected in this study.

Age and Education variables refer to the age and education level of the respondents, respectively. Despite a few exceptions, the typical finding on the relationship between both variables and giving in the literature is that it is positive (Bekkers and Wiepking 2007; Lammam and Gabler 2012). Marital Status, Gender, and Race are binary variables that take the value of 1 (or 2 ) if the respondent is married, woman and white, zero (or 1 ) otherwise. Marriage is mostly positively related to giving, while the finding on the impact of Race and Gender on charity giving is ambiguous (Bekkers and Wiepking 2007).

One of the most important explanatory variables of our model is Religiosity. Major religions have much in common, and adherents to these religions are expected to adopt similar behavioral codes, like protecting the needy, being honest, working hard, living modestly, and

\footnotetext{
${ }^{9}$ Available at https://www.cafonline.org/
} 
respecting others' rights. Hence, the level of religiosity has always been considered an influential variable in social research, and studies have shown that religiosity affects some behavioral outcomes positively (lannacconne 1998). As mentioned above, all religions promote giving, and studies in this realm find a positive association between religious involvement and giving (Bekkers and Wiepking 2007; Lammam and Gabler 2012; Gittell and Tebaldi 2006). A positive relationship between religiosity and giving is expected in this study as well.

The variables we use to test the validity of IE's assumption about the giving behavior of Muslims are Muslim and Religiosity*Muslim. Muslim is a dummy variable that shows the religious affiliation of a respondent. It takes the value of 1 if the respondent is a Muslim and 0 otherwise. The sign of this dummy should be significantly positive if, on average, Muslims give more than others. Religiosity*Muslim is an interaction term that indicates Muslims with different levels of religiosity. As we mentioned above, we expect that religious people give more than others. We expect this interaction term should also be significantly positive, implying that Muslims at a certain level of religiosity give more than a person who has the same level of religiosity but a member of another faith if the assumption of IE is realistic.

\subsection{Evidence from the US}

As we mentioned above, in order to investigate the charitable giving behavior of Muslims and compare their level of giving with members of other religions, the 2012 General Social Survey (GSS) is used first. In the 2012 survey, 1,974 individuals across the US are polled on their concerns, experiences, attitudes, and practices. We only used the data derived from questions regarding surveyees' charitable giving and volunteerism attitudes and some other demographical, behavioral, and social variables which are discussed above. The data is downloaded from the official website of GSS and is cleaned by removing answers like "No Answer", "Not Applicable", and "Don't Know".

The survey allows us to consider giving in both pecuniary (money) and nonpecuniary (volunteering) terms. The data is derived from two questions that are used as indicators of giving frequency, "During the past 12 months, how often have you... given money to charity?" and "During the past 12 months, how often have you... done volunteer work for a 
charity?" Possible answers to these questions are "not at all in the past year," "once in the past year," "at least 2 or 3 times in the past year," "once a month," "once a week," or "more than once a week" and are assigned values ranging from 6 to 1 respectively. The original order of the answers is reversed to interpret the results easily.

Here, A short description of these explanatory variables is presented.

Age is the age of the respondent.

Income is the total family income of the respondent, which takes a value on a scale from 1 to 12, in which higher values refer to higher income levels.

Gender is a dummy variable, which takes the value 2 if the respondent is a woman, and 1 otherwise.

Education refers to the highest degree received by the respondent, which takes a value on a scale from 0 to 4 , in which higher values refer to higher degrees.

Marital Status refers to the marital status of the respondent and takes the value 1 if the respondent is married, and 0 otherwise.

Race refers to the race of the respondent and takes the value 1 if the respondent is white, and 0 otherwise.

Religiosity refers to the religiosity of the respondent and is measured by the frequency of attendance to religious services, which takes a value on a scale from 0 to 8 , where higher values refer to a higher level of attendance to religious services.

Muslim takes the value 1 if the respondent is Muslim and 0 otherwise.

Some summary statistics of the variables are given in table X. Two points are remarkable. First, is the lower average frequency of volunteering activities compared to money donation, which is probably because it is easier for people to give money rather than give time. Second, is the very limited number (13) of Muslim respondents, which is understandable for a survey conducted in the West. 
Table 1 about here

Our two giving variables are regressed on the abovementioned explanatory variables separately by using the ordered logit model, and the results are reported in Table $\mathrm{X} .{ }^{10}$ First, the relationship between our control variables and giving is estimated (column 1 of each separate regression). Secondly, insignificant variables are dropped and the base models are obtained (column 2 of each separate regression). Then, we added our two variables defining Muslims to the models separately and made two more estimations (column 3 and 4 of each separate regression), which show whether giving behavior of Muslims is different from the others.

As shown in column 1 and 2 of the "Give money to charity" estimations, results suggest that there exists a positive relationship between independent variables Age, Education and Income, and the frequency of donating money. Also, married and white people donate more frequently than the others, even accounting for income differences. The impact of Gender on donating money is found insignificant. These findings are consistent with the previous literature.

First two columns of the "Do voluntary work" estimations imply a significant and positive relationship between Education and frequency of doing voluntary work, as with donating money. Similarly, white people participate in volunteering more frequently. However, Income has no significant impact on doing voluntary work, which is understandable since it is not directly linked to money-like donations. ${ }^{11}$ The impact of Gender is also found insignificant and is dropped from the regression, like Income. Again, unlike in the "Give money to charity" estimations, being married has a negative impact on the frequency of volunteering activities, and there is a negative relationship between Age and voluntary work. Taken together, these facts can be explained as follows: to participate in voluntary activities one needs time and energy rather than money. Younger people participate in voluntary activities more frequently because they have more energy and, probably, time as well. Unmarried people also participate in voluntary activities more frequently because they likely

\footnotetext{
${ }^{10}$ In all regressions, Likelihood Ratio statistics are significant at the 1 percent level; thus, we can conclude that all the variables together do have a significant influence on giving.

${ }^{11}$ No doubt, it is linked to opportunity cost of the time devoted to volunteering activities.
} 
have no kids to take care of or a husband/wife waiting for them to spend time together and, therefore, have more time for voluntary activities.

Table 2 about here

One of the most important findings derived from these estimations is the positive relationship between religiosity and both forms of giving (donating money and volunteering). These estimations mean that more pious people, measured by frequency of attending religious services, follow the orders of their own faith and give more irrespective of their religious denomination. This finding is consistent with our expectations. Yet, our basic question is still remains unanswered: Do Muslims give more?

To answer this question, two new explanatory variables (Religiosity*Muslim and Muslim) are added to the base models. These new variables give insignificant results for both types of giving (3rd and 4th columns of the regressions) implying that Muslims' are not giving more than the others.

\subsection{Evidence from Europe}

The analysis of GSS data showed us that the giving behavior of Muslims is not different from the members of the other religions; however, the data we used to reach this conclusion is derived from a survey conducted in the US and number of Muslims who participated in this survey was quite low. Does the same analysis give same results in another part of the world? To answer this question and provide extra evidence for our first result, we applied the same analysis to a different dataset, ESS. The same model and variables are used with a few changes.

The first difference of this analysis is the form of the question from which the dependent variable data is derived. Unlike GSS data, in which respondents were asked about frequency of their giving activities, ESS respondents were asked whether they had donated/volunteered to an organization for humanitarian aid, human rights, minorities, or immigrants in the past year. Affirmative answers are coded as 1 and negative answers are coded as 0 ; hence, the dependent variable is binary. 
Explanatory variables are the same with few exceptions.

Age is the age of the respondent.

Income is the total family income of the respondent, which takes a value on a scale from 1 to 12, in which higher values refer to higher income levels.

Gender is a dummy variable, which takes the value 2 if the respondent is a woman, and 1 otherwise.

Education refers to the highest degree received by the respondent, which takes a value on a scale from 1 to 5 in which higher values refer to higher degrees.

Marital Status refers to the marital status of the respondent and takes the value 1 if the respondent is married and 0 otherwise.

Religiosity refers to the religiosity of the respondent and is measured by the frequency of attendance to religious services, which takes a value on a scale from 1 to 7 in which higher values refer to a higher level of attendance to religious services in ESS. The order is reversed for convenience.

Muslim takes the value of 1 if the respondent is Muslim and 0 otherwise.

As can be seen, the race variable is absent since no question about the respondent's race is available in ESS. Other variables are the same except for some changes in the coding format. The most important difference of this model (ESS) from the previous one (GSS) is the addition of country dummies. Unlike GSS, ESS is a cross-country survey conducted in 22 countries in Europe, but data for donating money and volunteering is available for only 17 countries. In order to grasp country-specific factors that may affect giving behavior of respondents, country dummies are added to the model.

Summary statistics of the variables are given in the following table $\mathrm{X}$.

Table 3 about here 
Summary statistics of ESS show similar patterns to the GSS data. Again, the occurrence of donating money is much higher than volunteering. ${ }^{12}$ The share of Muslims is also low in ESS; however, both percentage ( 3 percent) and number (789) of Muslim respondents are much higher than GSS.

When regressing the two giving variables on our explanatory variables using the binary logit model, we obtained the results reported in table X. Results regarding money donation show that all our explanatory variables except Marital Status were found to have significant effects on donating money. All variables had a positive relationship with giving money to a charity, which is inconsistent with previous studies and our RSS results (column 1 and 2 of "giving money to a charity" regressions). Application of the same procedure of replacing the dependent variable with "Do voluntary work" produced the results shown in column 1 of the "Do voluntary work" section. The reduced model, after conducting stepwise selection, found the Education, Gender, and Religiosity variables to be positive and significant contributors (column 2 of "Do voluntary work" section).

As shown above in the ESS models, religiosity was found to have a significant influence on both donating money and volunteering, like in the GSS. In order to find whether Muslims, on average, or Religious Muslims behave differently from the others, Muslim and Religiosity*Muslim variables are added to both models individually. In all estimations, these variables were again found insignificant, like in the GSS estimations, implying that Muslims are not different from the others in donating money or time.

Table 4 about here

\section{Conclusion}

Economics literature has witnessed the revival of Islamic economics over the last few decades. It began with a critique of conventional economics. They reacted to the value-free

\footnotetext{
${ }^{12}$ One should keep in mind that dependent variables are not identical in the two models.
} 
nature of conventional economics and mentioned the need for an approach that is equipped with Islamic values for a more efficient use of resources and a more just economic and social order. The second stage was to construct an alternative theory based on Islamic values and teaching. Islamic economists have devoted extensive efforts to applying Islamic principles and have built models adopting value-based behavioral assumptions, an interest ban, and giving, which are distinguishing features of Islamic economic theory. These models have shown that an economy operating according to Islamic principles would produce more efficient and fairer results.

In the third stage, we may expect new studies both from inside or outside this subfield, that test the hypotheses and promised results of these newly developing models in this newly developing subfield. This study, testing the giving behavior of Muslims, was a preliminary effort in this regard. By using two comprehensive surveys from two different parts of the world, we have shown that countries with more pious citizens give more than others, but we found no difference between the giving behavior of Muslims and the others.

It should be clearly stated that this result does not imply that Muslims do not give Zakat or other forms of Islamic charity. As we mentioned above, the research alleges that despite the existence of devout Muslims who adhere to Islamic values strictly and fulfill their Zakat obligations properly, divergence from basic Islamic values and Zakat evasion is pervasive, even in the countries ruled with Sharia. Our finding is compatible with these two groups of studies and indicates that Muslims give, yet do not give more than the members of other religions-which also promote charitable giving-as suggested by Islamic economists, probably because the majority of them do not behave altruistically enough as ordered in Islamic teachings and assumed in IE.

Supplementary evidence in this regard will contribute to the development of IE in many ways. First, Islamic economists have criticized conventional economics, due to its unrealistic assumptions. Replacing a theory based on unrealistic assumptions with another theory based on other unrealistic assumptions would be considered the same as expecting two wrongs to make a right, from an Islamic economics' standpoint. Second, some say that Islamic economics is about an ideal that would be reached if the majority of a society adopted Islamic teachings. This raises the question of why Muslims - at least the majority- 
have not adopted behavioral patterns prescribed by the Quran in about 1,500 years, even in Muslim-majority countries. Third, as other religions also promote charitable giving and Islam itself does not compare its giving behavior with others, Islamic economists may reconsider the compatibility of the behavioral assumptions of IE, regarding giving, with Islam. Finally, increasing numbers of studies supporting the findings of this study or raising questions about the validity of IE'S assumptions may cause IE to evolve in a different direction, like conventional economics experienced during the seventeenth and eighteenth centuries.

\section{References}

Ahmad, M. (2000). Income distribution in Muslim countries vis-a-vis non-Muslim countries. PhD Thesis submitted to Bahauddin Zakaria University Department of Economics.

Ahmed, H. (2002). Analytical tools of islamic economics: a modified marginalist approach. In Theoretical foundations of Islamic economics (pp. 123-143). Jeddah.

Behdad, S. (1994). A disputed utopia: Islamic economics in Iran. Comparative Studies in Society and History, 36(4), 775-813.

Bekkers, R., \& Wiepking, P. (2007). Generosity and Philanthropy: A Literature Review. Retrieved from Available at SSRN: http://ssrn.com/abstract=1015507

Berger, I. (2006). The Influence of Religion on Philanthropy in Canada. Voluntas: International Journal of Voluntary and Nonprofit Organizations, 17(2), 115-132.

Chapra, M. (2008). Islamic Economics: What It Is and How It Developed. In R. Whaples, EH.Net Encyclopedia. Retrieved from http://eh.net/encyclopedia/islamic-economics-what-it-is-andhow-it-developed/

Chapra, M. U. (1992). Islam and the economic challenge. The Islamic Foundation.

Chapra, M. U. (2000). Is it necessary to have Islamic economics? Journal of Socio-Economics, 29(1), 21-37.

Charities Aid Foundation. (2010-2015). World Giving Index.

CIVICUS. (2013). Enabling Environmet Index 2013. 
DAWN. (2003, October 28). Corruption in Zakat distribution alleged. Retrieved February 03, 2017, from www.dawn.com: http://www.dawn.com/news/122008/corruption-in-zakatdistribution-alleged

Everatt, D., Habib, A., Maharaj, B., \& Nyar, A. (2005). Patterns of Giving in South Africa. Voluntas: International Journal of Voluntary and Nonprofit Organizations, 16(3), 275-291.

Gittell, R., \& Tebaldi, E. (2006). Charitable giving: Factors influencing giving in U.S. states. Nonprofit and Voluntary Sector Quarterly, 35(4), pp. 721-736.

Gledhill, R. (2013, 7 20). Muslims 'are Britain's top charity givers'. The Times.

Hasan, Z. (2005). Treatment of Consumption in Islamic Economics: An appraisal. J.KAU: Islamic Economics, 18(2), 29-46.

Hasan, Z. (2011, January). Scarcity, self-interest and maximization from Islamic angle. MPRA Paper, No. 29414.

Hoge, D., \& Yang, F. (1994). Determinants of Religious Giving in American Denominations: Data from Two Nationwide Surveys. Review of Religious Research, 36(2), 123-148.

Iannacconne, L. (1998). Introduction to economics of religion. Journal of Economic Literature, 36(3), 1465-1496.

Ikbal, M. (1985). Zakah, moderation and aggregate consumption in an Islamic economy. Journal of Research in Islamic Economics, 3(1), 45-61.

Khan, F. (1984). Macro Consumption Function in an Islamic Framework. Journal of Research in Islamic Economics, 1(2), 1-24.

Khan, F. (2013). Theorizing Islamic Economics: search for a framework for Islaimic economic analysis. JKAU Islamic Economics Journal, 26(1), 209-241.

Khan, M. A. (1987). Methodology of Islamic Economics. Journal of Islamic Economics, 1(1), 17-33.

Kuran, T. (1989). On the Notion of Economic Justice in Contemporary Islamic Thought. International Journal of Middle East Studies, 21(2), 171-191. 
Kuran, T. (1995). Islamic Economics and the Islamic Subeconomy. Journal of Economic Perspectives, 9(4), 155-173.

Lammam, C., \& Gabler, N. (2012, March/April). Determinants of charitable giving: A review of the literature. Fraser Forum, pp. 12-15.

Mahomedy, A. C. (2013). Islamic economics: still in search of an identity. International Journal of Social Economics, 40(6), $556-578$.

PEW Research Center. (2012). The Global Religious Landscape: A Report on the Size and Distribution of the World's Major Religious Groups as of 2010. Pew Research Center.

Scheherazade, R., \& Askari, H. (2010). How Islamic are Islamic Countries? Global Economy Journal, 10(2).

The Economist. (2008, September 18). Less than white? Retrieved February 03, 2017, from www.economist.com: http://www.economist.com/node/12273885

World Values Survey Association. (n.d.). WORLD VALUES SURVEY Wave 6 2010-2014 OFFICIAL AGGREGATE v.20150418. Asep/JDS, Madrid SPAIN.

Zaman, A. (2012). An islamic critique of neoclassical economics. Pakistan Economic Review, 9-62. 


\begin{tabular}{|c|c|c|c|c|c|}
\hline \multicolumn{7}{|c|}{ Table 1. Summary Statistics for GSS 2012, using the observations 1 - 1974} \\
(missing values were skipped) \\
\hline Variable & Mean & Median & S.D. & Min & Max \\
\hline GIVCHRTY & 1,67 & 3.00 & 1.34 & 1.00 & 6.00 \\
\hline VOLCHRTY & 1.12 & 1.00 & 1.47 & 1.00 & 6.00 \\
\hline AGE & 48.2 & 47.0 & 17.7 & 18.0 & 89.0 \\
\hline RELIGIOSITY & 3.49 & 3.00 & 2.84 & 0.000 & 8.00 \\
\hline EDUCATION & 1.60 & 1.00 & 1.23 & 0.000 & 4.00 \\
\hline MARITAL STATUS & 0.456 & 0.000 & 0.498 & 0.000 & 1.00 \\
\hline RACE & 0.748 & 1.00 & 0.434 & 0.000 & 1.00 \\
\hline INCOME & 10.9 & 12.0 & 2.35 & 1.00 & 12.0 \\
\hline MUSLIM & 0.00661 & 0.000 & 0.0810 & 0.000 & 1.00 \\
\hline GENDER & 1.55 & 2.00 & 0.497 & 1.00 & 2.00 \\
\hline
\end{tabular}




\begin{tabular}{|c|c|c|c|c|c|c|c|c|}
\hline \multicolumn{9}{|c|}{$\begin{array}{l}\text { Table 2. Ordered logit model: Do Muslims give more? } \\
\text { General Social Survey regression results }\end{array}$} \\
\hline \multirow{2}{*}{$\begin{array}{l}\text { Dependent } \\
\text { Variable }\end{array}$} & \multicolumn{4}{|c|}{ Give money to charity } & \multicolumn{4}{|c|}{ Do voluntary work } \\
\hline & (1) & (2) & (3) & (4) & (1) & (2) & (3) & (4) \\
\hline Age & $\begin{array}{l}0.0191758^{\mathrm{a}} \\
(0.00330828)\end{array}$ & $\begin{array}{l}0.0192023^{\mathrm{a}} \\
(0.00330613)\end{array}$ & $\begin{array}{l}0.0192067^{\mathrm{a}} \\
(0.00330621)\end{array}$ & $\begin{array}{l}0.0191179^{\mathrm{a}} \\
(0.00330847)\end{array}$ & $\begin{array}{l}-0.00505245 \\
(0.00355877)\end{array}$ & $\begin{array}{l}-0.0066315^{b} \\
(0.00331484)\end{array}$ & $\begin{array}{l}-0.00662571^{b} \\
(0.00331558)\end{array}$ & $\begin{array}{l}-0.00669024^{b} \\
(0.00331628)\end{array}$ \\
\hline Religiosity & $\begin{array}{l}0.183996^{\mathrm{a}} \\
(0.0208057)\end{array}$ & $\begin{array}{l}0.184379^{a} \\
(0.0207378)\end{array}$ & $\begin{array}{c}0.184323^{a} \\
(0.0207397)\end{array}$ & $\begin{array}{c}0.184667^{\mathrm{a}} \\
(0.0207981)\end{array}$ & $\begin{array}{c}0.215096^{\mathrm{a}} \\
(0.0221605)\end{array}$ & $\begin{array}{c}0.226624^{\mathrm{a}} \\
(0.0211098)\end{array}$ & $\begin{array}{c}0.226989^{a} \\
(0.0211121)\end{array}$ & $\begin{array}{c}0.224771^{\mathrm{a}} \\
(0.0211384)\end{array}$ \\
\hline Education & $\begin{array}{c}0.273925^{\mathrm{a}} \\
(0.0467132)\end{array}$ & $\begin{array}{c}0.274182^{\mathrm{a}} \\
(0.0467001)\end{array}$ & $\begin{array}{c}0.273634^{\mathrm{a}} \\
(0.0467604)\end{array}$ & $\begin{array}{c}0.268126^{\mathrm{a}} \\
(0.0468395)\end{array}$ & $\begin{array}{c}0.379513^{\mathrm{a}} \\
(0.0494220)\end{array}$ & $\begin{array}{c}0.361428^{\mathrm{a}} \\
(0.0453908)\end{array}$ & $\begin{array}{c}0.362806^{\mathrm{a}} \\
(0.0454255)\end{array}$ & $\begin{array}{c}0.363318^{\mathrm{a}} \\
(0.0455233)\end{array}$ \\
\hline Marital Status & $\begin{array}{l}0.399946^{\mathrm{a}} \\
(0.116032)\end{array}$ & $\begin{array}{l}0.399263^{\mathrm{a}} \\
(0.115994)\end{array}$ & $\begin{array}{l}0.398062^{a} \\
(0.116109)\end{array}$ & $\begin{array}{l}0.395603^{\mathrm{a}} \\
(0.116288)\end{array}$ & $\begin{array}{l}-0.274085^{b} \\
(0.124110)\end{array}$ & $\begin{array}{l}-0.226021^{b} \\
(0.114131)\end{array}$ & $\begin{array}{l}-0.221119^{c} \\
(0.114230)\end{array}$ & $\begin{array}{l}-0.213652^{c} \\
(0.114424)\end{array}$ \\
\hline Race & $\begin{array}{l}0.279863^{b} \\
(0.132480)\end{array}$ & $\begin{array}{l}0.280709^{b} \\
(0.132418)\end{array}$ & $\begin{array}{l}0.281613^{b} \\
(0.132466)\end{array}$ & $\begin{array}{l}0.292778^{b} \\
(0.133469)\end{array}$ & $\begin{array}{l}0.250997^{c} \\
(0.138217)\end{array}$ & $\begin{array}{l}0.261272^{b} \\
(0.130944)\end{array}$ & $\begin{array}{l}0.257130^{b} \\
(0.131059)\end{array}$ & $\begin{array}{l}0.239970^{c} \\
(0.131744)\end{array}$ \\
\hline Income & $\begin{array}{c}0.105919^{a} \\
(0.0268284)\end{array}$ & $\begin{array}{c}0.105481^{\mathrm{a}} \\
(0.0267541)\end{array}$ & $\begin{array}{c}0.105585^{\mathrm{a}} \\
(0.0267558)\end{array}$ & $\begin{array}{c}0.106003^{\mathrm{a}} \\
(0.0267749)\end{array}$ & $\begin{array}{l}0.00386750 \\
(0.0273922)\end{array}$ & & & \\
\hline Gender & $\begin{array}{l}0.0246035 \\
(0.109117)\end{array}$ & & & & $\begin{array}{l}0.0514236 \\
(0.116187)\end{array}$ & & & \\
\hline Religiosity*Muslim & & & $\begin{array}{l}0.0489936 \\
(0.222204)\end{array}$ & 28 & & & $\begin{array}{l}-0.182035 \\
(0.186018)\end{array}$ & \\
\hline Muslim & & & & 0.853216 & & & & -1.17458 \\
\hline
\end{tabular}




\begin{tabular}{|c|c|c|c|c|c|c|c|c|}
\hline & & & & $(0.753401)$ & & & & $(0.841058)$ \\
\hline cut1 & $\begin{array}{c}7.64057^{a} \\
(0.437326)\end{array}$ & $\begin{array}{c}7.60124^{a} \\
(0.400877)\end{array}$ & $\begin{array}{c}7.60195^{a} \\
(0.400856)\end{array}$ & $\begin{array}{c}7.60376^{a} \\
(0.401841)\end{array}$ & $\begin{array}{c}4.73721^{a} \\
(0.421690)\end{array}$ & $\begin{array}{c}4.61347^{a} \\
(0.257500)\end{array}$ & $\begin{array}{c}4.61519^{a} \\
(0.257549)\end{array}$ & $\begin{array}{l}4.59082^{a} \\
(0.257875)\end{array}$ \\
\hline cut2 & $\begin{array}{c}6.19283^{a} \\
(0.404083)\end{array}$ & $\begin{array}{c}6.15334^{a} \\
(0.364000)\end{array}$ & $\begin{array}{c}6.15420^{a} \\
(0.363984)\end{array}$ & $\begin{array}{c}6.15680^{a} \\
(0.365095)\end{array}$ & $\begin{array}{c}3.80016^{\mathrm{a}} \\
(0.404959)\end{array}$ & $\begin{array}{c}3.68360^{\mathrm{a}} \\
(0.232265)\end{array}$ & $\begin{array}{c}3.68534^{\mathrm{a}} \\
(0.232301)\end{array}$ & $\begin{array}{c}3.66108^{a} \\
(0.232676)\end{array}$ \\
\hline cut3 & $\begin{array}{c}4.85558^{a} \\
(0.391539)\end{array}$ & $\begin{array}{c}4.81599^{a} \\
(0.349791)\end{array}$ & $\begin{array}{c}4.81706^{a} \\
(0.349797)\end{array}$ & $\begin{array}{c}4.81965^{a} \\
(0.350939)\end{array}$ & $\begin{array}{c}2.97310^{a} \\
(0.397343)\end{array}$ & $\begin{array}{c}2.83230^{a} \\
(0.218710)\end{array}$ & $\begin{array}{c}2.83364^{a} \\
(0.218728)\end{array}$ & $\begin{array}{l}2.80961^{\mathrm{a}} \\
(0.219152)\end{array}$ \\
\hline cut4 & $\begin{array}{c}3.19481^{a} \\
(0.377638)\end{array}$ & $\begin{array}{c}3.15517^{\mathrm{a}} \\
(0.334112)\end{array}$ & $\begin{array}{c}3.15611^{\mathrm{a}} \\
(0.334112)\end{array}$ & $\begin{array}{c}3.15654^{\mathrm{a}} \\
(0.335156)\end{array}$ & $\begin{array}{c}1.97468^{\mathrm{a}} \\
(0.392247)\end{array}$ & $\begin{array}{c}1.85730^{\mathrm{a}} \\
(0.208888)\end{array}$ & $\begin{array}{c}1.85758^{\mathrm{a}} \\
(0.208881)\end{array}$ & $\begin{array}{c}1.83336^{\mathrm{a}} \\
(0.209387)\end{array}$ \\
\hline cut5 & $\begin{array}{c}2.40039^{a} \\
(0.371605)\end{array}$ & $\begin{array}{c}2.36084^{a} \\
(0.327509)\end{array}$ & $\begin{array}{c}2.36172^{a} \\
(0.327506)\end{array}$ & $\begin{array}{c}2.36092^{a} \\
(0.328584)\end{array}$ & $\begin{array}{c}1.45388^{a} \\
(0.390221)\end{array}$ & $\begin{array}{c}1.35752^{\mathrm{a}} \\
(0.206087)\end{array}$ & $\begin{array}{c}1.35703^{\mathrm{a}} \\
(0.206073)\end{array}$ & $\begin{array}{c}1.33244^{\mathrm{a}} \\
(0.206638)\end{array}$ \\
\hline No. of obs. & 1147 & 1147 & 1147 & 1145 & 1148 & 1292 & 1292 & 1290 \\
\hline Log Likelihood & -1510.122 & -1669.920 & -1669.895 & -1668.312 & -1510.220 & -1669.820 & -1669.323 & -1668.273 \\
\hline LR test & $\begin{array}{c}X 2(7)= \\
521.688^{\mathrm{a}}\end{array}$ & $x^{2}(6)=521.637^{a}$ & $\begin{array}{c}\text { X2 (7) } \\
521.687^{\mathrm{a}}\end{array}$ & $\begin{array}{c}\mathrm{X}^{2}(7) \\
=519.551^{\mathrm{a}}\end{array}$ & $X^{2}(6)=346.598^{a}$ & $\begin{array}{c}X^{2}(5)= \\
387.951^{a}\end{array}$ & $\begin{array}{c}X^{2}(5)= \\
388.945^{a}\end{array}$ & $\begin{array}{c}\mathrm{X}^{2}(5)= \\
388.412^{\mathrm{a}}\end{array}$ \\
\hline
\end{tabular}




\begin{tabular}{|c|c|c|c|c|c|}
\hline \multicolumn{6}{|c|}{$\begin{array}{l}\text { Table 3. Summary Statistics for ESS 2002, using the observations } 1 \text { - } 42359 \\
\text { (missing values were skipped) }\end{array}$} \\
\hline Variable & Mean & Median & S.D. & Min & Max \\
\hline GIVCHRTY & 0.113 & 0.000 & 0.317 & 0.000 & 1.00 \\
\hline VOLCHRTY & 0.0185 & 0.000 & 0.135 & 0.000 & 1.00 \\
\hline AGE & 46.5 & 45.0 & 18.3 & 14.0 & 110. \\
\hline EDUCATION & 2.91 & 3.00 & 1.31 & 1.00 & 5.00 \\
\hline GENDER & 1.53 & 2.00 & 0.499 & 1.00 & 2.00 \\
\hline INCOME & 6.21 & 6.00 & 2.46 & 1.00 & 12.0 \\
\hline MARITAL STATUS & 0.524 & 1.00 & 0.499 & 0.000 & 1.00 \\
\hline RELIGIOSITY & 5.32 & 6.00 & 1.57 & 1.00 & 7.00 \\
\hline MUSLIM & 0.0301 & 0.000 & 0.171 & 0.000 & 1.00 \\
\hline COUNTRY 1 & 0.0533 & 0.000 & 0.225 & 0.000 & 1.00 \\
\hline COUNTRY 2 & 0.0366 & 0.000 & 0.188 & 0.000 & 1.00 \\
\hline COUNTRY 3 & 0.0481 & 0.000 & 0.214 & 0.000 & 1.00 \\
\hline COUNTRY 4 & 0.0472 & 0.000 & 0.212 & 0.000 & 1.00 \\
\hline COUNTRY 5 & 0.0484 & 0.000 & 0.215 & 0.000 & 1.00 \\
\hline COUNTRY 6 & 0.0448 & 0.000 & 0.207 & 0.000 & 1.00 \\
\hline COUNTRY 7 & 0.0606 & 0.000 & 0.239 & 0.000 & 1.00 \\
\hline COUNTRY 8 & 0.0590 & 0.000 & 0.236 & 0.000 & 1.00 \\
\hline COUNTRY 9 & 0.0408 & 0.000 & 0.198 & 0.000 & 1.00 \\
\hline COUNTRY 10 & 0.0558 & 0.000 & 0.230 & 0.000 & 1.00 \\
\hline COUNTRY 11 & 0.0498 & 0.000 & 0.218 & 0.000 & 1.00 \\
\hline COUNTRY 12 & 0.0356 & 0.000 & 0.185 & 0.000 & 1.00 \\
\hline COUNTRY 13 & 0.0689 & 0.000 & 0.253 & 0.000 & 1.00 \\
\hline COUNTRY 14 & 0.0359 & 0.000 & 0.186 & 0.000 & 1.00 \\
\hline COUNTRY 15 & 0.0472 & 0.000 & 0.212 & 0.000 & 1.00 \\
\hline COUNTRY 16 & 0.0285 & 0.000 & 0.166 & 0.000 & 1.00 \\
\hline COUNTRY 17 & 0.0357 & 0.000 & 0.185 & 0.000 & 1.00 \\
\hline
\end{tabular}




\begin{tabular}{|c|c|c|c|c|c|c|c|c|}
\hline \multirow{3}{*}{$\begin{array}{l}\text { Dependent } \\
\text { Variable }\end{array}$} & \multicolumn{8}{|c|}{$\begin{array}{l}\text { Table 4. Binary logit model: Do Muslims give more? } \\
\text { European Social Survey regression results }\end{array}$} \\
\hline & \multicolumn{4}{|c|}{ Give money to charity } & \multicolumn{4}{|c|}{ Do voluntary work } \\
\hline & (1) & (2) & (3) & (4) & (1) & (2) & (3) & (4) \\
\hline Constant & $\begin{array}{l}-4.32401^{\mathrm{a}} \\
0.169037\end{array}$ & $\begin{array}{l}-4.31774^{\mathrm{a}} \\
0.168863\end{array}$ & $\begin{array}{l}-3.97806^{\mathrm{a}} \\
0.209474\end{array}$ & $\begin{array}{l}-4.00077^{\mathrm{a}} \\
0.213077\end{array}$ & $\begin{array}{l}-5.06102^{\mathrm{a}} \\
(0.372317)\end{array}$ & $\begin{array}{l}-4.88089^{a} \\
(0.224791)\end{array}$ & $\begin{array}{l}-4.94526^{\mathrm{a}} \\
0.283754\end{array}$ & $\begin{array}{l}-4.93656^{\mathrm{a}} \\
0.285545\end{array}$ \\
\hline Age & $\begin{array}{l}0.00407801^{\mathrm{a}} \\
0.00120868\end{array}$ & $\begin{array}{l}0.00448006^{\mathrm{a}} \\
0.00116863\end{array}$ & $\begin{array}{l}0.00284234^{c} \\
0.00153737\end{array}$ & $\begin{array}{l}0.00294541^{\mathrm{c}} \\
0.00154253\end{array}$ & $\begin{array}{l}0.00238072 \\
(0.00276939)\end{array}$ & & & \\
\hline Education & $\begin{array}{l}0.324918^{\mathrm{a}} \\
0.0157722\end{array}$ & $\begin{array}{l}0.324657^{\mathrm{a}} \\
0.0157627\end{array}$ & $\begin{array}{l}0.303010^{\mathrm{a}} \\
0.0208713\end{array}$ & $\begin{array}{l}0.303521^{\mathrm{a}} \\
0.0208897\end{array}$ & $\begin{array}{c}0.298479^{\mathrm{a}} \\
(0.0361995)\end{array}$ & $\begin{array}{c}0.329413^{\mathrm{a}} \\
(0.0286966)\end{array}$ & $\begin{array}{l}0.388598^{\mathrm{a}} \\
0.0366865\end{array}$ & $\begin{array}{l}0.388230^{\mathrm{a}} \\
0.0367053\end{array}$ \\
\hline Income & $\begin{array}{l}0.0834116^{\mathrm{a}} \\
0.0106201\end{array}$ & $\begin{array}{l}0.0877128^{\mathrm{a}} \\
0.0101323\end{array}$ & $\begin{array}{l}0.102313^{\mathrm{a}} \\
0.0136340\end{array}$ & $\begin{array}{l}0.102749^{\mathrm{a}} \\
0.0136391\end{array}$ & $\begin{array}{l}0.0491618^{b} \\
(0.0249878)\end{array}$ & & & \\
\hline Marital Status & $\begin{array}{l}0.0564934 \\
0.0415650\end{array}$ & & & & $\begin{array}{c}-0.140682 \\
(0.0958105)\end{array}$ & & & \\
\hline Religiosity & $0.152028^{\mathrm{a}}$ & $0.153712^{\mathrm{a}}$ & $0.172330^{a}$ & $0.172268^{a}$ & $0.282681^{a}$ & $0.216918^{a}$ & $0.264653^{\mathrm{a}}$ & $0.265222^{\mathrm{a}}$ \\
\hline
\end{tabular}




\begin{tabular}{|c|c|c|c|c|c|c|c|c|}
\hline & 0.0136244 & 0.0135654 & 0.0178256 & 0.0178085 & $(0.0298483)$ & $(0.0247162)$ & 0.0335584 & 0.0334789 \\
\hline Muslim & & & & $\begin{array}{c}0.0523833 \\
0.155478\end{array}$ & & & & $\begin{array}{c}-0.105166 \\
0.313221\end{array}$ \\
\hline country2 & $\begin{array}{l}0.221448 \\
0.164602\end{array}$ & $\begin{array}{l}0.208114 \\
0.164299\end{array}$ & $\begin{array}{c}0.0698076 \\
0.186261\end{array}$ & $\begin{array}{l}0.0788047 \\
0.186867\end{array}$ & $\begin{array}{c}0.669343^{b} \\
(0.328183)\end{array}$ & $\begin{array}{c}0.473344^{b} \\
(0.221718)\end{array}$ & $\begin{array}{l}0.519430^{c} \\
0.279015\end{array}$ & $\begin{array}{l}0.516728^{c} \\
0.279139\end{array}$ \\
\hline Country3 & $\begin{array}{l}1.55635^{\mathrm{a}} \\
0.114634\end{array}$ & $\begin{array}{l}1.54015^{\mathrm{a}} \\
0.113989\end{array}$ & $\begin{array}{l}1.42546^{\mathrm{a}} \\
0.135874\end{array}$ & $\begin{array}{l}1.43448^{\mathrm{a}} \\
0.136567\end{array}$ & $\begin{array}{l}81.12011^{a} \\
(0.256974)\end{array}$ & $\begin{array}{c}1.00602^{\mathrm{a}} \\
(0.158483)\end{array}$ & $\begin{array}{l}1.15893^{\mathrm{a}} \\
0.215422\end{array}$ & $\begin{array}{l}1.15678^{\mathrm{a}} \\
0.215434\end{array}$ \\
\hline Country5 & $\begin{array}{l}0.817859^{\mathrm{a}} \\
0.124024\end{array}$ & $\begin{array}{l}0.803142^{\mathrm{a}} \\
0.123539\end{array}$ & $\begin{array}{l}0.657105^{\mathrm{a}} \\
0.149400\end{array}$ & $\begin{array}{l}0.664623^{\mathrm{a}} \\
0.149917\end{array}$ & $\begin{array}{c}0.578766^{b} \\
(0.279191)\end{array}$ & $\begin{array}{c}0.576726^{\mathrm{a}} \\
(0.181944)\end{array}$ & $\begin{array}{l}0.944547^{\mathrm{a}} \\
0.220606\end{array}$ & $\begin{array}{l}0.943554^{\mathrm{a}} \\
0.220606\end{array}$ \\
\hline Country6 & $\begin{array}{l}1.06413^{\mathrm{a}} \\
0.124046\end{array}$ & $\begin{array}{l}1.05697^{\mathrm{a}} \\
0.123921\end{array}$ & $\begin{array}{l}0.967595^{\mathrm{a}} \\
0.150872\end{array}$ & $\begin{array}{l}0.976200^{\mathrm{a}} \\
0.151466\end{array}$ & $\begin{array}{l}-0.499634 \\
(0.360542)\end{array}$ & $\begin{array}{l}0.932692^{\mathrm{a}} \\
(0.169675)\end{array}$ & $\begin{array}{c}1.11802^{\mathrm{a}} \\
0.225777\end{array}$ & $\begin{array}{l}1.11667^{a} \\
0.225771\end{array}$ \\
\hline Country7 & $\begin{array}{l}-1.45434^{\mathrm{a}} \\
0.236215\end{array}$ & $\begin{array}{l}-1.45578^{\mathrm{a}} \\
0.236210\end{array}$ & $\begin{array}{l}-1.64546^{\mathrm{a}} \\
0.250516\end{array}$ & $\begin{array}{l}-1.63510^{a} \\
0.251046\end{array}$ & $\begin{array}{c}0.375646 \\
(0.352583)\end{array}$ & $\begin{array}{c}-0.794841^{\mathrm{a}} \\
(0.277696)\end{array}$ & $\begin{array}{r}-0.554062^{c} \\
0.290704\end{array}$ & $\begin{array}{r}-0.556648^{\circ} \\
0.290805\end{array}$ \\
\hline Country8 & $\begin{array}{l}0.404865^{b} \\
0.161711\end{array}$ & $\begin{array}{l}0.402581^{b} \\
0.161703\end{array}$ & $\begin{array}{c}0.0704458 \\
0.193219\end{array}$ & $\begin{array}{l}0.0814051 \\
0.193856\end{array}$ & $\begin{array}{c}1.04521^{\mathrm{a}} \\
(0.254370)\end{array}$ & $\begin{array}{l}0.0398663 \\
(0.246073)\end{array}$ & $\begin{array}{c}0.0199193 \\
0.309158\end{array}$ & $\begin{array}{c}0.0172682 \\
0.309192\end{array}$ \\
\hline
\end{tabular}




\begin{tabular}{|c|c|c|c|c|c|c|c|c|}
\hline Country9 & $\begin{array}{l}1.52995^{\mathrm{a}} \\
0.113185\end{array}$ & $\begin{array}{l}1.52084^{\mathrm{a}} \\
0.112978\end{array}$ & $\begin{array}{l}1.34559^{\mathrm{a}} \\
0.137162\end{array}$ & $\begin{array}{l}1.35381^{\mathrm{a}} \\
0.137818\end{array}$ & $\begin{array}{l}-0.987780^{b} \\
(0.399351)\end{array}$ & $\begin{array}{l}0.795127^{a} \\
(0.162658)\end{array}$ & $\begin{array}{l}0.901312^{\mathrm{a}} \\
0.224092\end{array}$ & $\begin{array}{l}0.899349^{a} \\
0.224184\end{array}$ \\
\hline Country10 & $\begin{array}{c}-0.529266^{\mathrm{a}} \\
0.167533\end{array}$ & $\begin{array}{c}-0.522379^{a} \\
0.167440\end{array}$ & $\begin{array}{c}-0.637001^{a} \\
0.179526\end{array}$ & $\begin{array}{c}-0.624366^{\mathrm{a}} \\
0.180638\end{array}$ & $\begin{array}{c}1.25249^{\mathrm{a}} \\
(0.267567)\end{array}$ & $\begin{array}{l}-1.28721^{\mathrm{a}} \\
(0.332750)\end{array}$ & $\begin{array}{l}-1.30511^{\mathrm{a}} \\
0.377637\end{array}$ & $\begin{array}{l}-1.30876^{\mathrm{a}} \\
0.377833\end{array}$ \\
\hline Country11 & $\begin{array}{l}1.29641^{\mathrm{a}} \\
0.122995\end{array}$ & $\begin{array}{l}1.28538^{\mathrm{a}} \\
0.122697\end{array}$ & $\begin{array}{l}1.14457^{\mathrm{a}} \\
0.147540\end{array}$ & $\begin{array}{l}1.15325^{\mathrm{a}} \\
0.148061\end{array}$ & $\begin{array}{c}0.295630 \\
(0.277009)\end{array}$ & $\begin{array}{c}1.04706^{\mathrm{a}} \\
(0.175095)\end{array}$ & $\begin{array}{l}1.29389^{a} \\
0.227495\end{array}$ & $\begin{array}{l}1.29262^{\mathrm{a}} \\
0.227402\end{array}$ \\
\hline Country12 & $\begin{array}{l}1.05116^{\mathrm{a}} \\
0.113867\end{array}$ & $\begin{array}{l}1.04355^{\mathrm{a}} \\
0.113719\end{array}$ & $\begin{array}{l}0.913358^{\mathrm{a}} \\
0.133501\end{array}$ & $\begin{array}{l}0.921388^{\mathrm{a}} \\
0.134100\end{array}$ & $\begin{array}{l}0.705811^{b} \\
(0.293413)\end{array}$ & $\begin{array}{c}0.260429 \\
(0.175005)\end{array}$ & $\begin{array}{l}0.499050^{b} \\
0.219656\end{array}$ & $\begin{array}{l}0.497573^{b} \\
0.219652\end{array}$ \\
\hline Country13 & $\begin{array}{l}0.848984^{\mathrm{a}} \\
0.134147\end{array}$ & $\begin{array}{l}0.850024^{\mathrm{a}} \\
0.134139\end{array}$ & $\begin{array}{l}0.898727^{\mathrm{a}} \\
0.162425\end{array}$ & $\begin{array}{l}0.909483^{\mathrm{a}} \\
0.163342\end{array}$ & $\begin{array}{l}0.519508^{c} \\
(0.283662)\end{array}$ & $\begin{array}{l}0.483451^{b} \\
(0.206484)\end{array}$ & $\begin{array}{l}0.800338^{\mathrm{a}} \\
0.261940\end{array}$ & $\begin{array}{l}0.797458^{\mathrm{a}} \\
0.262109\end{array}$ \\
\hline Country14 & $\begin{array}{l}0.948998^{\mathrm{a}} \\
0.121089\end{array}$ & $\begin{array}{l}0.940788^{\mathrm{a}} \\
0.120913\end{array}$ & $\begin{array}{l}0.820804^{\mathrm{a}} \\
0.137057\end{array}$ & $\begin{array}{l}0.831366^{\mathrm{a}} \\
0.137836\end{array}$ & $\begin{array}{l}0.0173214 \\
(0.437905)\end{array}$ & $\begin{array}{l}0.423829^{b} \\
(0.195798)\end{array}$ & $\begin{array}{l}0.456528^{c} \\
0.247747\end{array}$ & $\begin{array}{l}0.454139^{c} \\
0.247686\end{array}$ \\
\hline Country15 & $\begin{array}{l}0.232635 \\
0.190912\end{array}$ & $\begin{array}{l}0.228414 \\
0.190895\end{array}$ & $\begin{array}{l}0.116611 \\
0.211729\end{array}$ & $\begin{array}{l}0.127803 \\
0.212468\end{array}$ & $\begin{array}{l}-0.261090 \\
(0.437422)\end{array}$ & $\begin{array}{c}-0.00857857 \\
(0.278876)\end{array}$ & $\begin{array}{c}-0.118325 \\
0.360729\end{array}$ & $\begin{array}{r}-0.121819 \\
0.360894\end{array}$ \\
\hline Country16 & $\begin{array}{l}0.211967 \\
0.174493\end{array}$ & $\begin{array}{l}0.210692 \\
0.174504\end{array}$ & $\begin{array}{l}0.0799599 \\
0.192571\end{array}$ & $\begin{array}{l}0.0915565 \\
0.193390\end{array}$ & $\begin{array}{c}1.15051^{\mathrm{a}} \\
(0.264227)\end{array}$ & $\begin{array}{l}-0.563876 \\
(0.350045)\end{array}$ & $\begin{array}{c}-0.604106 \\
0.431886\end{array}$ & $\begin{array}{r}-0.607489 \\
0.431999\end{array}$ \\
\hline No. of obs. & 26246 & 26246 & 16533 & 16533 & 26246 & 38484 & 24257 & 24257 \\
\hline Log Likelihood & -9204.223 & -9205.148 & -5357.298 & -5357.246 & -2421.525 & -3347.876 & -1994.322 & -1994.285 \\
\hline LR test & $\begin{array}{c}x^{2}(22)= \\
2421.82^{a}\end{array}$ & $\begin{array}{c}x^{2}(21)= \\
2419.97^{a}\end{array}$ & $\begin{array}{c}x^{2}(22)= \\
1678.83^{a}\end{array}$ & $\begin{array}{c}X 2(22)= \\
1678.94^{\text {a }}\end{array}$ & $\begin{array}{c}X^{2}(22)= \\
350.471^{a}\end{array}$ & $\begin{array}{c}X^{2}(19)= \\
412.519^{a}\end{array}$ & $\begin{array}{l}x^{2}(20)= \\
379.882\end{array}$ & $\begin{array}{l}x^{2}(20)= \\
379.955\end{array}$ \\
\hline
\end{tabular}

